\title{
Schadeverhaal na misdrijven: ervaringen van slachtoffers
}

\author{
Dr. J.D.M. van Dongen, mr. M.R. Heblyen \\ prof. mr. S.D. Lindenbergh*
}

\section{Inleiding}

Wanneer iemand schade lijdt als gevolg van een misdrijf, zijn er verschillende mogelijkheden om die schade vergoed te krijgen. Compensatie kan - kort gezegd - worden bereikt via een fonds (Schadefonds Geweldsmisdrijven, Waarborgfonds Motorverkeer), via een verzekering of via de dader zelf (indien bekend). Verhaal op de dader is mogelijk door een schaderegeling met behulp van de politie of het Openbaar Ministerie $(\mathrm{OM})$, door te voegen als benadeelde partij in het strafproces of langs de civielrechtelijke weg (aansprakelijkstelling/dagvaardingsprocedure). ${ }^{1}$

Wat ondernemen slachtoffers van delicten om hun schade vergoed te krijgen? Wat zijn hun overwegingen bij het al dan niet volgen van verschillende wegen en wat zijn hun feitelijke ervaringen bij schadeverhaal? Deze vragen stonden centraal in een onderzoek dat de auteurs in het voorjaar van 2013 deden. Dit artikel beoogt een verkorte weergave te bieden van de bevindingen. ${ }^{2}$ In paragraaf 2 zullen eerst de aanleiding en de context van dit onderzoek worden besproken, waarna in paragraaf 3 de onderzoeksopzet zal worden toegelicht. In paragraaf 4 wordt de steekproef globaal beschreven, met het oog op de in paragraaf 5 te bespreken bevindingen met betrekking tot de ervaringen met schadeverhaal. Een korte afronding volgt in paragraaf 6 .

\section{De context: meer aandacht voor slachtoffers van strafbare feiten}

De positie van slachtoffers van strafbare feiten en in het bijzonder het verhaal van schade door deze slachtoffers kunnen zich in de afgelopen decennia in een toenemende belangstelling verheugen. De verbetering van de positie van deze slacht-

* Dr. J.D.M. van Dongen is als universitair docent klinische psychologie verbonden aan het Instituut voor Psychologie van de Erasmus Universiteit Rotterdam. Mr. M.R. Hebly is als docent privaatrecht verbonden aan het Molengraaff Instituut voor privaatrecht van de Universiteit Utrecht. Prof. mr. S.D. Lindenbergh is hoogleraar privaatrecht aan de Erasmus School of Law van de Erasmus Universiteit Rotterdam.

1. Zie voor een gedetailleerde 'routekaart' voor schadeverhaal W.M. Schrama \& T. Geurts, Civiel schadeverhaal door slachtoffers van strafbare feiten. De rol van de civiele procedure: gebruik, knelpunten en oplossingsrichtingen, Den Haag: WODC 2012, p. 31 c.v.

2. Zie voor het volledige onderzoeksverslag J.D.M. van Dongen, M.R. Hebly \& S.D. Lindenbergh, 'Je hebt geluk als je van een pauw mag plukken'. Ervaringen van slachtoffers van strafbare feiten met het verhalen van hun schade, Den Haag: WODC 2013. offers past in een nationale en internationale ontwikkeling. ${ }^{3}$ Hoewel die positie geleidelijk aan structureel is verbeterd, is het de vraag wat de gevolgen zijn van de genomen maatregelen en of het nog beter kan. Het nationale beleid met betrekking tot de positie van slachtoffers van strafbare feiten is dan ook voorafgegaan door en gepaard gegaan met verschillende vormen van onderzoek. ${ }^{4}$ Recentelijk hebben Schrama en Geurts onderzoek gedaan naar de rol van de civiele procedure voor slachtoffers van strafbare feiten, waarbij zij de "juridische routekaart voor schadeverhaal' en het daadwerkelijke (kwantitatieve) gebruik daarvan hebben verkend. S Schrama en Geurts signaleren onder meer knelpunten bij het verhaal van schade via een civiele procedure. In hun onderzoek is ervoor gekozen geen slachtoffers te bevragen naar hun ervaringen met het verhaal van schade na strafbare feiten. Juist op die ervaringen was het door de auteurs verrichte onderzoek gericht, zij het dat het zich niet beperkte tot ervaringen met schadeverhaal via een civiele procedure, maar zich ook uitstrekte over de andere 'routes'. Het onderzoek heeft dus als doel een slachtofferperspectief aan de eerdergenoemde studies toe te voegen.

\section{De opzet van het onderzoek}

Voor het door de auteurs verrichte onderzoek zijn face-toface-diepte-interviews gehouden met een steekproef van 28 respondenten die hebben meegedaan aan de Slachtoffer-

3. In de nationale context vallen onder meer te noemen de versterking van de positie van de benadeelde partij in het strafproces door de Wet Terwee (1995), de invoering van een spreekrecht (2005) en de voorschotregeling ten aanzien van de schadevergoedingsmaatregel (2011). Internationale aandacht voor verbetering van de positie van slachtoffers van strafbare feiten blijkt bijvoorbeeld uit Richtlijn 2012/29/EU van 25 oktober 2012, PbEU 2012, L 315/57 tot het creëren van minimumnormen.

4. Noemenswaardig in deze context zijn o.m. S. van Wingerden, M. Moerings \& J. van Wilsem, De praktijk van schadevergoeding voor slachtoffers van misdrijven, Den Haag: WODC/Boom Juridische uitgevers 2007, A. ten Boom \& K.F. Kuijpers, m.m.v. M.H. Moene, Behoeften van slachtoffers van delicten. Een systematische literatuurstudie naar behocften zoals door slachtoffers zelf geuit, Den Haag: WODC/Boom Juridische uitgevers 2008 .

5. Schrama \& Geurts 2012. 
monitor. ${ }^{6}$ Later zijn langs verschillende wegen nog acht respondenten aan de steekproef toegevoegd om een zo evenredig mogelijke spreiding over de vier 'hoofdroutes voor verhaal' te bereiken.

In totaal zijn 36 respondenten ondervraagd en ingedeeld in de hoofdcategorieën (a) voeging benadeelde partij, (b) schikking politie/OM, (c) Schadefonds en (d) civiele procedure. De eigen (inboedel)verzekering is niet als hoofdroute aangemerkt, maar de ervaringen hiermee konden als 'bijvangst' uit de andere interviews worden meegenomen. De categorie 'voeging benadeelde partij' bestond uit achttien respondenten; de andere drie categorieën steeds uit zes. De oververtegenwoordiging aan respondenten die gevoegd hebben als benadeelde partij valt deels toe te schrijven aan het gegeven dat vaak pas tijdens een interview de beproefde verhaalsroute kon worden vastgesteld; op voorhand was niet altijd duidelijk om welke route(s) het ging. De indeling naar hoofdroutes geeft overigens slechts een ruw beeld van routes die door de respondenten zijn bewandeld, aangezien in zestien gevallen diverse routes tegelijk of opeenvolgend zijn bewandeld (zie tabel 2). Wat binnen dit onderzoek onder de noemer 'schikking politie/OM' wordt geschaard, zijn gevallen waarin met hulp van politie of OM wordt getracht tot een schikking te komen. Van de zes respondenten die in deze categorie vallen, gaat het in vijf gevallen om een schaderegeling met de politie en in één geval om een voorwaardelijk sepot/transactie onder voorwaarden.

Het is van belang om de beperkingen van het onderzoek te benadrukken. Diepte-interviews kunnen een waardevolle bijdrage leveren bij het in kaart brengen van de percepties en ideeën van respondenten, maar binnen dit onderzoek is geen sprake van een representatieve steekproef om verantwoorde kwantitatieve uitspraken te doen met betrekking tot verhaalzoekende slachtoffers na strafbare feiten in het algemeen. Waardevol aan deze verkenning is niettemin dat men met het 'anekdotische' materiaal tot nuttige inzichten kan komen met betrekking tot de eventuele knelpunten en problemen bij het schadeverhaal door slachtoffers van een misdrijf.

\section{De steekproef}

\subsection{De delicten en de beproefde verhaalsroutes}

Het type strafbaar feit waar de respondenten mee zijn geconfronteerd, liep sterk uiteen (zie tabel 1). Hierbij dient te worden opgemerkt dat steeds wordt afgegaan op het verhaal zoals de respondent dit vertelt, waaraan de onderzoekers vervolgens een juridische duiding hebben gegeven. Waar de respondent nog over een dossier beschikte, is de juridische kwalificatie van het strafbare feit in de stukken gecontroleerd. Het meest voorkomende delict waarvan de geinterviewden het slachtoffer

6. M. Timmermans, J. van den Tillaart \& G. Homburg, Eerste meting slachtoffermonitor. Ervaringen van slachtoffers met justitiële slachtofferondersteuning. Deel 2: Openbaar Ministerie, Rechtspraak \& Slachtofferhulp Nederland, Den Haag: WODC 2013 (deelrapport). Het betreft 28 slachtoffers van gewelds- en vermogensmisdrijven van wie de dienstverlening door Slachtofferhulp Nederland in de periode van 1 februari tot 1 juni 2011 is afgesloten. waren geworden, bleek diefstal met braak (tien gevallen), gevolgd door de categorie mishandeling (acht gevallen).

Tabel 1: Frequentie van type strafbare feiten binnen steekproef

\begin{tabular}{lc}
\hline Strafbaar feit & Aantal respondenten \\
\hline Diefstal met braak & 10 \\
(Eenvoudige) mishandeling & 8 \\
Oplichting & 4 \\
Diefstal van betaalpas met pincode & 2 \\
Diefstal & 2 \\
Vernieling/beschadiging & 2 \\
Inbraak met geweld & 2 \\
Verkrachting en gijzeling & 1 \\
Toebrengen zwaar lichamelijk letsel & 1 \\
Moord & 1 \\
Seksuele uitbuiting & 1 \\
Gewapende overval & 1 \\
Schade door een gevaarlijk dier & 1 \\
\hline
\end{tabular}

Zoals reeds opgemerkt, bleek na het afnemen van de interviews dat zestien van de 36 respondenten een combinatie van routes hebben bewandeld (zie tabel 2 ). De combinatie die het meest voorkomt, is die van voegen in het strafproces en het aanspreken van de eigen (inboedel)verzekeraar; in de meeste gevallen naar aanleiding van een diefstal met braak, het meest voorkomende delict in de steekproef.

\subsection{Langs welke route hadden respondenten (enig) succes?}

In tabel 3 wordt weergegeven hoe vaak binnen de steekproef bepaalde typen schade geheel of gedeeltelijk zijn vergoed per verhaalsroute. Het gaat dus om een telling van het aantal gevallen waarin een respondent voor bepaalde schadeposten enig succes had bij het schadeverhaal. Van zeventien respondenten binnen de steekproef bleef de schade geheel onvergoed. Ook hier hebben de onderzoekers de door de respondenten genoemde schadeposten juridisch gekwalificeerd en ingedeeld in vermogensschade (zaaksschade, zuivere vermogensschade en letselschade) en ander nadeel dan vermogensschade. In dit overzicht is ook de eigen verzekering als route voor schadeverhaal meegenomen. 
Tabel 2: $\quad$ Voorkomende combinaties van schadeverbaalroutes

\begin{tabular}{ll}
\hline Combinatie & $\begin{array}{l}\text { Aantal res- } \\
\text { pondenten }\end{array}$ \\
\hline $\begin{array}{l}\text { Voegen strafrechtelijke procedure + eigen } \\
\text { verzekering }\end{array}$ & 8 \\
$\begin{array}{l}\text { Voegen strafrechtelijke procedure + civiele } \\
\text { procedure }\end{array}$ & 3 \\
$\begin{array}{l}\text { Voegen strafrechtelijke procedure + Schade- } \\
\text { fonds }\end{array}$ & 2 \\
Schadefonds + eigen verzekering & 1 \\
$\begin{array}{l}\text { Voegen strafrechtelijke procedure + schikking } \\
\text { Voegen strafrechtelijke procedure }+ \text { Schade- }\end{array}$ & 1 \\
fonds + eigen verzekering & 1 \\
\hline
\end{tabular}

Tabel 3: $\quad$ Verhaal van typen schade per verhaalsroute (gehele of gedeeltelijke vergoeding)

\begin{tabular}{lllll}
\hline & & Vermogensschade & $\begin{array}{l}\text { Ander } \\
\text { nadeel }\end{array}$ \\
& $\begin{array}{l}\text { Zaaks- } \\
\text { schade }\end{array}$ & $\begin{array}{l}\text { Zuivere ver- } \\
\text { mogens- } \\
\text { schade }\end{array}$ & Letsel \\
\hline Voeging & 5 & 1 & 1 & 1 \\
Schikking & 2 & 1 & 1 & 1 \\
$\begin{array}{l}\text { Schadefonds } \\
\text { Civiele }\end{array}$ & 1 & 2 & 4 & 3 \\
procedure & & 2 & & 1 \\
Verzekering & 9 & & 2 & \\
\hline
\end{tabular}

Voor een uitgebreide weergave van de steekproef zij verwezen naar het volledige onderzoeksrapport. ${ }^{7}$

\section{Bevindingen}

\subsection{De zoektocht naar respondenten}

In verband met de vraag wat slachtoffers van delicten ondernemen om hun schade te verhalen, verdient in de eerste plaats opmerking dat de steekproef op zichzelf al iets leert. Relatief weinig respondenten bleken een andere route te hebben beproefd dan voeging in de strafrechtelijke procedure. De nadere zoektocht naar respondenten uit de categorie 'schikking', maar vooral uit de categorie 'civiele procedure' bleek

7. Zie Van Dongen, Hebly \& Lindenbergh 2013, p. 10-36. niet eenvoudig. Tijdens gesprekken met advocaten (er zijn vijf advocatenkantoren benaderd die veel of uitsluitend letselschadezaken behandelen) vertelden zij dat zij in geval van letsel door een misdrijf (anders dan in het verkeer) zelden adviseren een civiele procedure te starten vanwege de verwachte gebrekkige verhaalsmogelijkheden bij de dader in relatie tot de emotionele belasting die een dergelijke procedure tegen een dader meebrengt. Dat doet vermoeden dat de perceptie en de reserves van advocaten ten anzien van de civiele procedure doorwerken in de afwegingen die slachtoffers maken. ${ }^{8}$ Ook ten aanzien van voeging in de strafrechtelijke procedure zijn door een van hen sterke reserves geuit, in het bijzonder dat de benadeelde dan persoonlijke informatie ten aanzien van zijn medische situatie moet verstrekken die hij in een civiele letselschadezaak met het oog op de bescherming van zijn persoonlijke levenssfeer niet hoeft prijs te geven. Ook de afhankelijkheid van het vervolgingsbeleid van en de informatieverstrekking door het $\mathrm{OM}$ werd als bezwaar van deze procedure genoemd.

Hoewel uiteindelijk toch enkele respondenten bereid zijn gevonden, was het - in het bijzonder voor wat betreft respondenten die de civiele procedure hadden beproefd - zoeken naar spelden in een hooiberg. ${ }^{9}$ Het verrichte onderzoek bevestigt de indruk dat natuurlijke personen die na een misdrijf een civiele procedure starten om hun schade te verhalen schaars zijn. Ook bevestigt de steekproef dat voeging in de strafrechtelijke procedure 'met stip' de door slachtoffers van misdrijven meest beproefde route is. De relatieve eenvoud van deze route, de ondersteuning door Slachtofferhulp Nederland en de (verdere) verbeteringen van deze procedure vormen daarvoor vermoedelijk een verklaring.

\subsection{Voeging als benadeelde partij}

Veel geïnterviewden die zich met hun vordering hebben gevoegd in het strafproces zijn op deze mogelijkheid gewezen door Slachtofferhulp Nederland en hebben de voegingspapieren ingevuld nadat zij deze kregen toegestuurd of aangereikt; voor hen was dit een min of meer vanzelfsprekende zaak. In enkele gevallen was weliswaar al een uitkering ontvangen vanwege een eigen verzekering, maar zijn er principiële redenen genoemd om ten aanzien van de resterende schade te voegen.

Uit de interviews met de respondenten die zich hadden gevoegd in de strafrechtelijke procedure zijn in het bijzonder de volgende drie aspecten opgevallen: (1) het principiële karakter van de motieven die ten grondslag liggen aan de keuze om verhaal te nemen, (2) de confrontatie die de respondenten hebben ervaren met hun bijrol in de procedure, en (3) het feit dat de voorschotregeling is genoemd als motief om te voegen.

Hoewel voor sommige respondenten voegen ten behoeve van verhaal uit financiële overwegingen gelet op de omvang van hun schade min of meer noodzaak was, hebben verschillende respondenten vooral principiële overwegingen genoemd

8. Vgl. Schrama \& Geurts 2012, p. 115 e.v.

9. Dit sluit aan bij de bevindingen van Schrama en Geurts (2012, p. 81 e.v.), die een zeer forse ondervertegenwoordiging signaleren van slachtoffers die via een civiele procedure verhaal zoeken. 
om te voegen. Dat bleek het meest uitdrukkelijk bij respondenten met een geringe resterende schade, doordat na een inbraak een deel van hun schade door een verzekering was gedekt. Het ging hun erom dat de dader er niet mee weg mocht komen. Verschillende respondenten zagen hun verhaalsactie dan ook, net als het doen van aangifte, als een soort 'burgerplicht'. Vaak zagen zij zelf heel goed in dat de verhaalsactie vanuit een kosten-batenperspectief mogelijk niet rationeel was, maar was het ondernemen van actie volgens hen van grotere emotionele, principiële of maatschappelijke betekenis. Deze bevinding onderstreept het principiële karakter van de mogelijkheid van schadeverhaal via voeging: ook slachtoffers met uitsluitend geringe resterende financiële schade betrekken in hun afweging uitdrukkelijk de 'immateriële baten' van het verhaal (erkenning, genoegdoening, vervulling van burgerschap). Voorbeelden van karakteristieke uitlatingen op dit punt zijn:

'Als iemand zoiets doet, dan wil je ook dat hij daarvoor boet.'

"Van een kale kip kun je niet plukken. Die man, daar is geen cent te halen. (...) Maar hij betaalt dus wel 12,50 euro per maand af. Voor mijn part doe je er 10 jaar over. Laat hem maar vooral wel voelen: "dit had ik dus beter niet kunnen doen".'

Opmerkelijk is dat verschillende respondenten benadrukten hoezeer zij hun positie als slachtoffer na voeging in het strafproces als een bijrol hadden ervaren omdat de aandacht en voorzieningen vooral naar de dader uitgingen. Dit aspect is uiteraard bekend uit eerder onderzoek, maar het viel ons op dat respondenten ondanks de substantiële verbeteringen van de positie van de benadeelde partij zich zo veelvuldig en dikwijls ook in nogal felle bewoordingen uitlieten over dit punt: ${ }^{10}$

'Dan staat er wel in de brief dat reiskosten en verblijflkosten niet worden betaald, maar voor de dader wordt alles gedaan, hoge piefen, bewaking, busje als vervoer ... (...) Je hebt als slachtoffer het gevoel dat je maar weinig te zeggen hebt.'

'Je kunt beter dader zijn dan slachtoffer, dan wordt er een blik hulpverleners opengetrokken! Justitie onderneemt niks en ik zit met de schade ... Als je dader bent komen de advocaten naar je toe. Ik voel me op een goedkope manier slachtoffer.'

Denkbaar is dat de steekproef - slachtoffers die hun schade slechts deels of geheel niet hebben kunnen verhalen - hier kleurend heeft gewerkt. Denkbaar is ook dat de grotere aandacht voor verbetering - en naar zich laat aannemen daardoor

10. Vgl. over de aard en gevolgen van het accessoire karakter van de vordering van de benadeelde partij J. Candido, De vordering benadeelde partij in het strafproces en de onevenredige belasting van het strafgeding, Trema 2011, p. 354-359. een toenemend gebruik - van de voegingsprocedure juist dit knelpunt explicieter aan het licht brengt. ${ }^{11}$ Het is natuurlijk een 'systeemkwestie': strafrechtelijke berechting van daders is iets fundamenteel anders dan het verhalen van schade, maar voor rechtzoekenden is dat systematische onderscheid allerminst vanzelfsprekend. Specifiek met betrekking tot schadeverhaal via voeging is de afhankelijkheid van het vervolgingsbeleid van het OM verschillende malen genoemd als obstakel. ${ }^{12}$ Weliswaar kan inmiddels (sinds 2011) ook vergoeding worden gevorderd van schade als gevolg van (tijdig) ad informandum ten laste gelegde delicten ${ }^{13}$ en stemt het OM zijn vervolgingsbeleid als het goed is mede af op de belangen van het slachtoffer, ${ }^{14}$ maar dat neemt niet weg dat er dan toch in elk geval vervolgd moet worden. Binnen de steekproef kwamen gevallen voor waarin sprake was van oplichting, waarbij het slachtoffer te horen kreeg dat het OM daar niets mee zou doen (en dat de civiele procedure de aangewezen verhaalsroute was):

'Dat vind ik raar. Je steelt een blikje cola en je wordt strafrechtelijk vervolgd. Je belazert de boel voor duizenden euro's en dan is dat "civiel" en dan doen ze er niks mee.'

Denkbaar is dat het hiervoor gesignaleerde principiële karakter van verschillende voegingen, maar wellicht ook het ogenschijnlijk 'automatische' voegen (formulieren worden toegestuurd, bij invullen wordt geholpen) de confrontatie met de bijrol hebben verscherpt.

Door een enkele respondent is de sinds 1 januari 2011 bestaande voorschotregeling van artikel $36 \mathrm{f}$ lid 6 van het Wetboek van Strafrecht (Sr), die is verbonden aan de schadevergoedingsmaatregel die via voeging kan worden bereikt, genoemd als belangrijk motief om te voegen. Het ligt in de rede om aan te nemen dat van deze maatregel voor benadeelden een aanzuigende werking naar de voeging uitgaat, in die zin dat voegen in gevallen waarin de voorschotregeling geldt een uitzicht biedt op daadwerkelijke betaling. ${ }^{15}$ Hoewel het risico van deze aanzuigende werking bij de totstandkoming van de voorschotregeling al is voorzien, is er nog weinig bekend over de wijze waarop en de mate waarin dit zich realiseert. $^{16}$

11. Dat zou aansluiten bij de inschatting van Van Dijk e.a. dat hervormingen van de positie van slachtoffers ook weer verwachtingen wekken waarin men eenvoudig teleurgesteld kan raken. Zie J. van Dijk \& M. Groenhuijsen, Benchmarking victim policies in the Framework of European Union Law, in: S. Walkate (red.), Handbook of victims and victimology, Devon: Willan Publishing 2007, p. 363-379.

12. Zie daarover ook reeds Van Wingerden, Moerings \& Van Wilsem 2007, p. 53.

13. Art. 361 lid 2 onder $b$ Sv jo. art. $36 f$ lid 1 Sr.

14. Aanwijzing Slachtofferzorg, Stcrt. 2010, 20476, p. 5.

15. Vgl. A.H. Sas, Strafrecht voor civilisten: de verbetering van de mogelijkheid om schade via het strafrecht te verhalen, TVP 2010, p. 86, die het niet wijzen op voeging door een advocaat als mogelijke beroepsfout kwalificeert.

16. Zie Kamerstukken II 2007/08, 30143, 28, waar wordt gesproken van een 'ongedekte cheque'. 


\subsection{Schikking door politie of $O M$}

Het aantal personen dat via politie of OM tot een schikking was gekomen, was in de benaderde steekproef opmerkelijk gering (een OM-schikking kwam er slechts eenmaal in voor). Niettemin zijn via een contact met een enkele schaderegelaar al voldoende aanvullingen gevonden van slachtoffers die een politieschikking hadden bereikt. Opmerkelijk is dat het daarbij niet alleen ging om zeer eenvoudige delicten ('boter-bij-deviszaken'), waarvoor de figuur van de politieschikking oorspronkelijk bedoeld is, maar ook om een complexere zaak, te weten een mishandeling. ${ }^{17}$ Verder zijn voor wat betreft deze route vooral de positieve ervaringen van slachtoffers opgevallen: de mogelijkheid op zich, de snelheid van de afwikkeling en ook dat geen direct contact tussen benadeelde en dader hoefde plaats te vinden.

\subsection{Schadefonds}

Ook het aantal respondenten dat zich tot het Schadefonds Geweldsmisdrijven had gewend, was aanvankelijk gering, maar kon worden aangevuld met gerichte zoekacties. De bevindingen waren niet erg verrassend: men is vooral blij met het bestaan van het fonds en over de afwikkeling is men, op een enkele respondent na, te spreken. Op dit punt is ook ander onderzoek verschenen waaruit (ook) blijkt dat door slachtoffers het bestaan van het fonds hoog wordt gewaardeerd en dat het feit dat minder dan de volledige schade wordt vergoed als weinig bezwaarlijk, althans als begrijpelijk wordt gezien. ${ }^{18}$

\subsection{Schadeverhaal via een civiele procedure}

Hiervoor is aangestipt hoe moeilijk het was om respondenten te vinden die een civiele procedure hadden beproefd. Dat is op zichzelf al illustratief voor de betrekkelijke betekenis van deze route als het om schadeverhaal na misdrijven gaat.

De redenen die door respondenten worden genoemd, zijn veelzeggend: als hoog ingeschatte kosten ('advocaten declareren per seconde') afgewogen tegen de kans op succes in de procedure ('hoe bewijs ik wel wat het OM blijkens de vrijspraak niet gelukt is?') en in het uiteindelijke verhaal ('van een kale kip valt niet te plukken'), emotionele belasting door confrontatie met de dader, angst voor represailles en 'moegestreden' zijn na het beproeven van andere routes. Illustratief zijn de volgende uitlatingen:

'Ik heb het allemaal achter me gelaten. Dan moet ik een advocaat in de arm nemen, en voordat die weet waar het over gaat ben je al zoveel geld kwijt, en het is nog maar de vraag of het wat oplevert.'

'Je haalt je veel op de hals, maar wat levert het op? Je hebt geluk als je van een pauw mag plukken ...'

17. Vgl. Aanwijzing Slachtofferzorg 2010, p. 4.

18. Zie J.D.W.E. Mulder, Compensation: the victim's perspective (diss. Tilburg), Oisterwijk: Wolf Legal Publishers 2013, p. 81 e.v. en 111 e.v.
'Ik wil geen slapende honden wakker maken, nu is het rustig en zien we hem niet ... Uiteindelijk denk je laat maar, je wilt rust en bent de strijd moe. Ik heb rust nu.'

'Dat betekent dat ik hem civielrechtelijk toch schuldig moet laten bevinden op datgene waarvoor hij strafrechtelijk vrijgesproken is? Dat wordt heel vervelend, natuurlijk.'

Op verschillende van deze elementen valt op zichzelf soms wel wat af te dingen. Zo is voor zaken onder de kantongrens geen rechtsbijstand vereist ${ }^{19}$ en kan bij ernstige gewelds- en zedendelicten bijvoorbeeld zijn voorzien in kosteloze rechtsbijstand (voor vermogensdelicten geldt dit niet). ${ }^{20}$ Voorts gelden voor civielrechtelijke bewijslevering minder hoge drempels dan voor strafrechtelijk bewijs. Confrontatie met de dader kan bovendien vanuit een processueel gelijkwaardige positie ook een kans op verwerking bieden. Niettemin lijkt in individuele gevallen een samenstel van verschillende van deze elementen een belangrijk motief om van een civiele verhaalsprocedure af te zien. De afweging van kosten tegen verwachte baten in samenhang met de emotionele belasting van de civiele procedure lijkt de doorslag te geven. Anders ligt het kennelijk vooral wanneer de financiële risico's van de procedure kunnen worden afgewenteld op een ander (een letselschadebureau dat op no-cure-no-paybasis werkt, een rechtsbijstandverzekering) of wanneer de baten (een groot schadebedrag zoals bij oplichting) kennelijk worden vermoed tegen de lasten op te wegen en de lasten met andere gedupeerden kunnen worden gedeeld.

Soms speelde kennelijk ook onwetendheid of onbegrip een rol: zo was in een antal gevallen de mogelijkheid van een civiele procedure in het geheel niet bekend bij de respondent. Soms was door Slachtofferhulp Nederland geadviseerd van een civiele procedure af te zien omdat al een voeging was beproefd en de respondent dan weer van voren af aan zou moeten beginnen met een nieuwe procedure. En enkele malen was men in de war gebracht door informatie uit correspondentie van het OM of de rechtbank. Met name brieven waarin werd vermeld dat de verdachte was vrijgesproken, maar dat niettemin een civiele procedure kon worden overwogen, leidden tot onbegrip, dan wel tot de uitroep dat dit dan toch kansloos leek. Op dat punt valt dus wel wat te verbeteren, maar de zojuist genoemde meer fundamentele belemmeringen worden daarmee niet weggenomen.

Het geringe gebruik van de civiele procedure voor schadeverhaal is in die zin opmerkelijk, omdat de civiele procedure voor slachtoffers met letsel in de literatuur wel is aangemerkt als een procedure met een 'positief potentieel' waar het de bevrediging van bij slachtoffers bestaande immateriële behoef-

19. Het is overigens zeer de vraag of de complexiteit van de materie en de risico's van confrontatic met de dader het entameren van een kantonprocedure zonder rechtsbijstand na een misdrijf niet in de weg staan.

20. Art. 44 lid 4 Wet op de rechtsbijstand. 
ten betreft. ${ }^{21}$ Zo zou het civiele aansprakelijkheidsrecht tegemoet (kunnen) komen aan de behoefte om de dader te confronteren, als benadeelde het eigen verhaal te kunnen doen, te participeren in het proces, met respect te worden bejegend, maatschappelijk erkend te worden en invloed uit te oefenen op het uiteindelijke resultaat. Daarbij moet wel worden aangetekend dat het hier gaat om een studie die uitsluitend betrekking had op slachtoffers van ongevallen, waarbij in veruit de meeste gevallen sprake zal zijn geweest van dekking door een aansprakelijkheidsverzekering, zodat de risico's van verhaalbaarheid in dergelijke gevallen geen gewicht in de schaal legden. Met betrekking tot dit 'positieve potentieel' merken wij verder op dat niet eenvoudig is vast te stellen wat het relatieve belang van deze immateriële behoeften is ten opzichte van de materiële behoefte om daadwerkelijk schade vergoed te krijgen. Het is bovendien aannemelijk dat als de financiële behoefte niet wordt bevredigd - de vordering wordt afgewezen of verhaal blijkt uiteindelijk niet mogelijk - de immateriële winsten van het civiele proces verdampen en zelfs in hun tegendeel (teleurstelling en secundaire victimisatie) verkeren. $\mathrm{Nu}$ met name dit laatste risico (onverhaalbaarheid) in geval van misdrijven relatief groot is, is het de vraag of dat positieve potentieel van het civiele aansprakelijkheidsrecht op dit gebied wel zo groot is. Daar komt nog bij dat de civiele procedure in geval van misdrijven bijzondere emotionele risico's meebrengt. Zo werden door de respondenten de confrontatie met de dader, de emotionele belasting daarvan en angst voor represailles als belemmeringen genoemd. Deze risico's worden in geval van een misdrijf stellig anders beleefd dan in geval van een ongeval, waarna de procedure feitelijk tegen een aansprakelijkheidsverzekeringsmaatschappij wordt gevoerd. Concluderend is het dus voor serieuze twijfel vatbaar of de mogelijke immateriële voordelen van een civiele procedure voor slachtoffers van misdrijven opwegen tegen de nadelen en risico's van een dergelijke procedure.

Al met al zien wij in het onderhavige onderzoek een bevestiging van de knelpunten ten aanzien van civiel schadeverhaal die eerder naar aanleiding van interviews met advocaten, rechters en wetenschappers werden opgetekend. ${ }^{22}$ De civiele procedure werd door onze respondenten doorgaans gezien als een 'last resort' met ernstige obstakels en een gering perspectief op daadwerkelijk verhaal. Opmerkelijk was in dit verband nog wel dat verschillende respondenten niet zozeer de duur van de civiele procedure op zichzelf noemden als knelpunt - over de inschatting van die duur is van respondenten geen informatie verkregen -, maar vooral de bedenking dat het na eerder beproefde verhaalsroutes nog weer een extra stap zou zijn die in de weg zou staan aan afronding van de zaak. Voor verschillende respondenten was het duidelijk te veel gevraagd om na een niet of gedeeltelijk geslaagde voegingsprocedure alsnog een

21. Vgl. R.M.E. Huver, K.A.P.C. van Wees, A.J. Akkermans \& N.A. Elbers Slachtoffers en aansprakelijkheid. een onderzoek naar behoeften, verwachtingen en ervaringen van slachtoffers en hun naasten mer betrekking tot het civiele aansprakelijkheidsrecht. Deel I: Terreinverkenning, Den Haag: WODC 2007, p. 81 e.v.

22. Zie Schrama \& Geurts 2012. civiele procedure te starten. Hieruit zou kunnen worden afgeleid dat de bij verschillende respondenten gesignaleerde principiële wens om verhaal te nemen in de loop van de tijd aan kracht inboet, althans dat wanneer het werkelijk op eigen initiatief en eigen risico aankomt, zoals de civiele procedure dat vergt, die wens toch minder sterk blijkt te zijn. Mogelijk ligt hierin ook een contradictie met wat voegers opmerkten over hun bijrol: waar zij in het civiele proces de hoofdrol zouden kunnen vervullen, laten zij die kans meestal uiteindelijk toch liggen.

\subsection{Rolvan (eigen) verzekeringen}

Naast bedenkingen bij de verschillende verhaalsroutes zijn door de respondenten ook uitgesproken positieve ervaringen geuit. De meest terugkerende was de ervaring met eigen verzekeringen. Dit is uiteraard geen verhaalsroute in eigenlijke zin, omdat een beroep wordt gedaan op een voorziening die men vooraf zelf en op eigen kosten in het leven heeft geroepen, maar een eigen verzekering voorziet wel bij uitstek in de financiële behoefte van het slachtoffer. Bovendien brengt het 'first party'-karakter van de inboedel-of zorgverzekering mee dat de betaling niet op 'vijandelijk terrein' (bij de dader) hoeft te worden bevochten, maar door een 'vriend' wordt voldaan. Niet alleen de daadwerkelijke betaling, maar ook de vlotte afwikkeling werd door de respondenten dan ook hoog gewaardeerd. Wel is de rol van dergelijke verzekeringen thans beperkt: zij dekken slechts bepaalde schadeposten (kosten van vervanging, kosten van herstel, kosten van geneeskundige behandeling) en doorgaans tot een bepaald niveau.

Deze positieve ervaringen met eigen verzekeringen roepen de vraag op of voor verzekeringen op dit gebied niet een grotere rol is weggelegd. In dit verband verdient aandacht dat al eerder is bepleit om de eigen aansprakelijkheidsverzekering (AVP), die in Nederland door een zeer groot aantal natuurlijke personen pleegt te worden afgesloten, bij wijze van 'zijspan' te voorzien van een first party-dekking voor gevolgen van geweldsmisdrijven. ${ }^{23}$ Op een enkele uitzondering na hebben verzekeraars daar toen niet voor gevoeld, maar wellicht is er thans een beter momentum voor het in het leven roepen van een dergelijke voorziening. De inmiddels tamelijk ruime ervaring met eigen verzekeringen bij letsel in de vorm van schadeverzekeringen voor inzittenden kunnen hier mogelijk ook een bron van inspiratie vormen. Een eigen verzekering heeft natuurlijk als nadeel dat het in zekere zin een sigaar uit eigen doos is (men betaalt er zelf voor) en dat schade wordt vergoed door een ander dan de veroorzaker. Het eerste kan een rationele keuze zijn, zeker in een situatie waarin de kans op schade betrekkelijk gering is, maar de schade soms groot uitvalt. Het tweede is tot op zekere hoogte onvermijdelijk, omdat de dader veelal gewoon geen verhaal biedt. In gevallen waarin verhaal niettemin mogelijk is, kan de verzekeraar op dit punt een rol vervullen door als professionele repeat player regres te nemen.

23. J.H. Wansink, Assurance oblige: de maatschappelijk verantwoord handelende verzekeraar in de 21e ceuw, AV\&S 2003, p. 50. 


\subsection{Genoemde knel-en verbeterpunten}

Hiervoor zijn al verschillende knelpunten aan de orde gekomen die door de respondenten zijn genoemd. Aan iedere respondent is tijdens het interview uitdrukkelijk de vraag gesteld wat de grootste knelpunten zijn die hij heeft ervaren bij het verhalen van schade. De daarop genoemde knelpunten laten zich als volgt rangschikken (zie tabel 4).

\section{Tabel 4: Genoemde grootste knelpunten bij het verhalen van schade}

\begin{tabular}{ll}
\hline Ervaren knelpunt & $\begin{array}{l}\text { Aantal keren } \\
\text { genoemd }\end{array}$ \\
\hline
\end{tabular}

Gebrekkige betrokkenheid en informatievoorziening $\mathrm{OM}$

Traagheid van de rechtsgang/het schadeverhaal

Dader biedt geen verhaal

Emotionele belasting

Gebrek aan inzicht in de procedures

\section{Slot}

De hiervoor geschetste bevindingen mogen - gezien de (omvang van de) steekproef - wellicht slechts als een indicatie worden beschouwd van wat slachtoffers van misdrijven ervaren met het verhalen van door strafbare feiten geleden schade. In zoverre kan men spreken van een 'empirische verkenning'. Niettemin geeft dit onderzoek te denken over de positie van slachtoffers van strafbare feiten en hun mogelijkheden tot schadeverhaal en kan men in 'anekdotisch materiaal' ook al voldoende aanleiding zien om op bepaalde punten verbetering na te streven. Belangrijke verbeterpunten die door de respondenten werden genoemd, zijn een betere communicatie door het OM, (nog) betere dienstverlening door Slachtofferhulp Nederland, versnelling van de verhaalsprocedure en bijstand van het slachtoffer door een (betaalde) advocaat. Een eerste aanbeveling die uit het onderzoek voortvloeit, is om, gelet op de grote tevredenheid van slachtoffers over hun eigen verzekering, te bezien in hoeverre verzekeraars in staat en bereid zijn om ten aanzien van schade door geweldsdelicten een first party-verzekering in het leven te roepen. Een tweede aanbeveling is om in ieder geval de standaardcommunicatie van het OM te laten toetsen door niet-juristen. Hiermee kunnen kleine stappen vooruit worden gezet in de verbetering van de positie van slachtoffers van misdrijven.

Verschillende verbeterpunten zijn in de afgelopen jaren al geadresseerd. Men denke aan de verbetering van de positie van de benadeelde partij door de voorschotregeling, het gewijzigde voegingscriterium, de mogelijkheid om te voegen bij ad informandum-zaken en de structurele bijstand door Slachtofferhulp Nederland. Voorts valt te denken aan de voorziening voor gratis rechtsbijstand bij geweldsdelicten.

Sommige knelpunten laten zich in het huidige bestel eenvoudigweg moeilijk (verder) wegnemen, zoals de beleving van de bijrol in het strafproces, het ontbreken van verhaalsmogelijkheden, de gepercipieerde traagheid van de rechtsgang en de emotionele belasting van het verhaalsproces. Met een alternatief voor verhaal in de vorm van een eigen verzekering zouden juist deze obstakels in bepaalde gevallen wel kunnen worden omzeild.

De verbetering van de rol van het OM bij het verhaal van schade is, gegeven de per definitie beperkte middelen en de hoofdtaak van strafvervolging, niet eenvoudig. Ook op dit punt zijn serieuze stappen genomen, bijvoorbeeld met de Aanwijzing Slachtofferzorg uit 2010. Waar het de communicatie door het OM betreft - de onbetwiste aanvoerder van de lijst van door de respondenten genoemde knelpunten en ook al bekend uit eerder onderzoek - lijkt niettemin nog steeds winst te behalen. ${ }^{24}$

24. Bijv. I. Koolen, M. van der Heide \& A. Ziegelaar, De tevredenheid van slachtoffers van misdrijven met de slachtofferzorg, Den Haag: WODC 2005, p. 37 en F. van Mierlo, A. Pemberton \& R. van Tol, Van tevredenheid naar kwaliteit: een meetinstrument voor de slachtofferzorg, Den Haag: WODC 2009, p. 49 e.v. 